\title{
PENGARUH LOAN TO DEPOSIT RATIO TERHADAP LABA OPERASIONAL (SUATU KASUS PADA PT.BANK MANDIRI (PERSERO) YANG TERDAFTAR DI BURSA EFEK INDONESIA)
}

\author{
Rita Patonah \\ Program Studi Pendidikan Akuntansi \\ Universitas Galuh Ciamis \\ Email: ritadearly@gmail.com \\ Diterima: Oktober 2018; Disetujui: Nopember 2018; dipublikasikan: Desember 2018
}

\begin{abstract}
ABSTRAK
Laba Operasi adalah laba yang diperoleh dari kegiatan utama perusahaan. Kegiatan utama bank untuk memperoleh laba adalah dari kegiatan kredit. Loan To Deposit Ratio adalah rasio yang membandingkan antara pinjaman yang disediakan dengan dana dari pihak ketiga. Semakin banyak orang yang menyimpan dana mereka di bank, semakin banyak kredit yang akan didistribusikan. Akibatnya, Laba Operasional akan meningkat. Tujuan penelitian ini adalah untuk mengetahui 1) Loan to Deposit Ratio, 2) Tingkat Laba Operasional, 3) Apakah ada pengaruh antara Loan To Deposit Ratio terhadap Laba Operasional. Teknik analisis data yang digunakan adalah koefisien korelasi product moment, koefisien determinasi, koefisien korelasi berganda, uji t, dan uji F. Hasil penelitian menunjukkan bahwa: 1) Tingkat Loan To Deposit Ratio di PT. Bank Mandiri selama lima tahun mengalami fluktuasi, 2) Operating Profit Ratio di PT. Bank Mandiri selama lima tahun meningkat setiap tahun, 4) Loan to Deposit Ratio berpengaruh signifikan terhadap Laba Operasional.
\end{abstract}

Kata kunci: Laba Operasional, Loan To Deposit Ratio, Non Performing Loan.

\begin{abstract}
Operating Profit is the profit earned from the main activities of the company. The main activities of banks to obtain profits are from credit activities. Loan To Deposit Ratio is a ratio that compares between loans provided with funds from third parties. The more people who keep their funds in the bank, the more credit will be distributed. As a result, Operating Profit will increase. The purpose of this research is to know 1) Loan To Deposit Ratio, 2) Operating Profit level, 3) Is there any influence between Loan To Deposit Ratio to Operating Profit. Data analysis techniques used are product moment correlation coefficient, coefficient of determination, multiple correlation coefficient, $t$ test, and $F$ test. The result of research shows that: 1) Loan To Deposit Ratio level at PT. Bank Mandiri for five years experience fluctuation, 2) Operating Profit Ratio at PT. Bank Mandiri for five years increases every year, 4) Loan To Deposit Ratio has significant effect to Operating Profit.
\end{abstract}

Keywords: Operating Profit, Loan To Deposit Ratio, Non Performing Loan. 


\section{PENDAHULUAN}

Bank berfungsi sebagai mediator keuangan, antara pihak yang kelebihan dana dengan pihak yang memerlukan dana. Peranan perbankan dirasakan sangat membantu masyarakat untuk memenuhi kebutuhan sehari-hari dan sebagian besar bisnis yang ada di Indonesia melibatkan perbankan sebagai sumber untuk pemenuhan kebutuhan dana perusahaan.

Menurut Kasmir (2011:11) "Bank merupakan lembaga keuangan yang kegiatan utamanya adalah menghimpun dana dari masyarakat dan menyalurkannya kembali dana tersebut ke masyarakat serta memberikan jasa Bank lainnya".

Melalui keberadaan Perbankan, perekonomian di Indonesia dapat berjalan dengan baik.Bank memiliki berbagai fungsi yang bertujuan untuk meningkatkan pertumbuhan ekonomi. Oleh karena itu agar bank dapat melangsungkan usahanya dengan optimal, maka bank harus mampu menjaga kepercayaan para nasabah. Bank juga harus mampu meningkatkan pelayanan kegiatan pokok bank dalam bentuk penerimaan dana berupa simpanan giro, deposito dan tabungan. Selain itu bank juga harus memaksimalkan pelayanannya dalam usaha menyalurkan dana dalam bentuk pemberian kredit.

Loan To Deposit Ratio merupakan rasio volume kredit yang diberikan oleh bank dengan jumlah dana dari pihak ketiga yang telah diterima oleh bank. Menurut Kasmir (2011:290) "Loan To Deposit Ratio merupakan rasio untuk mengukur komposisi jumlah kredit yang diberikan dibandingkan dengan jumlah dana masyarakat dan modal sendiri yang digunakan." Besarnya Loan To Deposit Ratio menurut peraturan pemerintah maksimum adalah $110 \%$.

Loan To Deposit Ratio akan berpengaruh terhadap perolehan laba perusahaan yang bersumber dari pendapatan bunga kredit. Akan tetapi aktivitas penyaluran kredit kepada nasabah juga dapat menimbulkan kerugian pada bank. Hal tersebut dapat terjadi jika nasabah tidak mampu melunasi kewajibannya kepada Bank. Loan To Deposit Ratio harus dalam kondisi yang baik agar dapat menjaga tingkat kesehatan Bank. Agar Loan To Deposit Ratiodalam kondisi yang baik maka Bank harus mampu meminimalisir kredit bermasala dan kredit macet.

Tujuan utama perusahaan adalah memperoleh laba dari kegiatan pokok perusahaan. Dalam dunia perbankan perolehan laba terbesar yaitu dari kegiatan penyaluran kredit. Menurut Soemarso (2004:227) dalam buku "Akuntansi Suatu Pengantar" Laba operasional adalah Selisih antara laba bruto dan beban usaha disebut laba usaha (income from operation) atau laba operasi (operating income). Laba usaha adalah laba yang diperoleh semata-mata dari kegiatan utama perusahaan".

Untuk mengetahui Loan To Deposit Ratio dan Non Performing Loan dari tahun 20112015 pada PT.Bank Mandiri Tbk dapat dilihat tabel berikut:

Tabel 1.1

Data Loan To Deposit Ratio

Periode 2011-2015

\begin{tabular}{cccccc}
\hline No & Tahun & $\begin{array}{c}\text { Jumlah } \\
\text { Kredit yang } \\
\text { Diberikan }\end{array}$ & $\begin{array}{c}\text { Dana Pihak } \\
\text { Ketiga }\end{array}$ & $\begin{array}{c}\text { Loan To } \\
\text { Deposit Ratio }\end{array}$ & $\begin{array}{c}\text { Perubahan } \\
\text { Naik/Turun }\end{array}$ \\
\hline 1 & 2011 & 311.093 & 384.728 & $80,86 \%$ & - \\
2 & 2012 & 384.581 & 442.837 & $86,84 \%$ & $5,98 \%$ (naik) \\
3 & 2013 & 467.170 & 503.996 & $91,78 \%$ & $4,94 \%$ (naik) \\
4 & 2014 & 523.101 & 583.538 & $89,64 \%$ & $-2,14 \%$ (turun) \\
5 & 2015 & 586.675 & 662.332 & $94,27 \%$ & $4,63 \%$ (naik) \\
\hline
\end{tabular}

Sumber: Bursa Efek Indonesia 
Dari tabel tersebut dapat dilihat bahwa Loan To Deposit Ratiopada PT Bank Mandiri berfluktuasi.Pada tahun 2012 LDR mengalami kenaikan 5,98\% dari tahun 2011. Begitu juga pada tahun 2013 mengalami kenaikan. Pada tahun 2014 LDR mengalami penurunan sebesar $2.14 \%$ dan kembali naik 4,63\% di tahun 2015 .

Untuk mengetahui Laba Operasional Perusahaan tahun 2011-2015 pada PT.Bank Mandiri Tbk dapat dilihat tabel berikut:

\section{Tabel 1.2}

Data Laba Operasional Perusahaan Periode 2011-2015

\begin{tabular}{ccc}
\hline Tahun & $\begin{array}{c}\text { Laba Operasional Perusahaan } \\
\text { (dalam miliar rupiah) }\end{array}$ & $\begin{array}{c}\text { Perubahan Naik/Turun } \\
\text { (dalam presentase) }\end{array}$ \\
\hline 2011 & 16.349 & - \\
2012 & 19.625 & $20,04 \%$ (naik) \\
2013 & 23.551 & $20 \%$ (naik) \\
2014 & 25.978 & $10,30 \%$ (naik) \\
2015 & 26.339 & $1,39 \%$ (naik) \\
\hline
\end{tabular}

Sumber: Bursa Efek Indonesia

Dari tabel tersebut dapat diketahui bahwa laba operasional perusahaan mengalami kenaikan setiap tahunnya dari Rp.16.348.933.000 pada tahun 2011 mengalami kenaikan sebesar 20,04\% menjadi Rp.19.625.471.000.Pada tahun 2013 mengalami kenaikan sebesar 20\% menjadi Rp.23.551.528.000.Pada tahun 2014 laba operasional kembali mengalami kenaikan sebesar 10,30\% menjadi Rp.25.978.106.000.Pada tahun 2015laba operasional mengalami kenaikan sebesar 1,39\% menjadi Rp.26.338.972.000.

Rumusan masalah dalam penelitian ini adalah sebagai berikut: 1. Bagaimana tingkat Loan To Deposit Ratio pada PT. Bank Mandiri? 2.Bagaimana tingkat Laba Operasional pada PT. Bank Mandiri? 3. Apakah terdapat pengaruh Loan to Deposit Ratio terhadap Laba Operasional PT. Bank Mandiri?

Sesuai dengan masalah yang telah dirumuskan, maka tujuan dari penelitian ini adalah untuk mengetahui Loan To Deposit Ratio pada PT. Bank Mandiri, Laba Operasional pada PT. Bank Mandiri dan Pengaruh Loan To Deposit Ratio terhadap Laba OperasionalPT. Bank Mandiri.

Grand theory yang digunakan untuk menguji permasalahan dalam penelitian ini adalah teori tentang laba. Menurut Soemarso (2004:245) "laba adalah selisih lebih pendapatan atas beban sehubungan dengan usaha untuk memperoleh pendapatan tersebut selama periode tertentu."Laba yang diperoleh bank merupakan selisih antara pendapatan dikurangi dengan beban-beban. Unsur pendapatan utama bank yaitu pendapatan bunga yang berasal dari pemberian kredit. Kualitas dan kuantitas kredit secara total akan berpengaruh terhadap perolehan laba. Semakin banyaknya dana yang disalurkan bank dalam bentuk kredit maka akan berpengaruh terhadap laba operasional bank. Karena dari aktivitas pemberian kredit bank akan memperoleh sumber pendapatan yang sangat besar yaitu pendapatan bunga. Semakin besar pendapatan bunga yang diperoleh bank maka akan semakin besar pula laba operasional yang akan diperoleh bank. Rasio untuk mengukur kuantitas pemberian kredit dibandingkan dengan dana yang dihimpun dari pihak ketiga yaitu Loan to Deposit Ratio.

Jika Loan To Deposit Ratio naik, maka diperkirakan Laba Operasional akan naik pula. Hal tersebut dikarenakan apabila angka LDR menunjukkan angka yang tinggi hal tersebut memiliki makna bahwa bank menyalurkan dana kredit dalam jumlah yang banyak. Semakin banyaknya dana bank yang disalurkan dalam bentuk pemberian kredit maka kesempatan bank untuk menambah pendapatan semakin tinggi. Karena dari penyaluran kredit bank akan 
memperoleh pendapatan bunga. Jika pendapatan bunga semakin tinggi maka diperkirakan bank akan memperoleh laba operasional yang tinggi. Jika penyaluran kredit meningkat maka diperkirakan pendapatan bunga kredit akan besar.Jika pendapatan bunga kredit besar maka diperkirakan laba akan meningkat.

Jika Loan To Deposit Ratio turun, maka diperkirakan Laba Operasional turun. Hal tersebut dikarenakan menurunnya Loan to Deposit Ratio menunjukkan bahwa penyaluran dana kredit yang dilakukan bank mengalami penurunan. Artinya bank hanya sedikit menyalurkan kredit. Jika volume kredit yang diberikan kepada masyarakat mengalami penuruan maka pendapatan bank juga akan mengalami penurunan. Dengan semakin sedikitnya penyaluran kredit, maka perolehan pendapatan utama bank dari pendapatan bunga akan semakin rendah. Dengan semakin rendahnya pendapatan bank dari pendapatan bunga maka hal tersebut akan menyebabkan laba operasional juga akan mengalami penurunan.

Berdasarkan kerangka pemikiran diatas maka paradigma penelitian ini dapat digambarkan sebagai berikut :

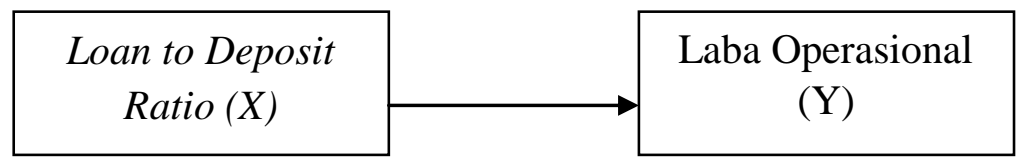

Gambar 2.1

Paradigma Penelitian

Hipotesis dalam penelitian ini adalah "Terdapat Pengaruh Loan to Deposit Ratio terhadap Laba Operasional PT. Bank Mandiri”.

\section{METODE}

Metode yang digunakan dalam penelitian ini yaitu metode deskriptif. Menurut Darmadi (2013:186) "penelitian deskriptif merupakan metode penelitian yang berusaha menggambarkan dan meninterpretasi objek sesuai dengan apa adanya, penelitian ini juga sering disebut non eksperimen, karena pada penelitian ini tidak melakukan kontrol dan memanipulasi variabel penelitian."

Penelitian ini dilakukan dengan menggunakan pendekatan kuantitatif. Analisis data yang digunakan adalah analisis Koefisien Determinasi dengan angka kasar, dimana terlebih dahulu dicari nilai $r$ dengan menggunakan Korelasi Product Moment. Analisis Koefisien Determinasi digunakan untuk mengukur pengaruh antara variabel bebas $(\mathrm{X})$ terhadap variabel terikat $(\mathrm{Y})$, yaitu Loan to Deposit Ratio (X) terhadap Laba Operasional (Y).

\section{HASIL DAN PEMBAHASAN}

\section{Loan to Deposit Ratio pada PT. Bank Mandiri Tbk.}

Loan To Deposit Ratio PT. Bank Mandiri pada tahun 2011-2015 mengalami fluktuasi, hal tersebut terjadi karena kondisi makro ekonomi tidak stabil yang disebabkan oleh tingkat suku bunga, dan tingkat inflasi. Pada tahun 2011 Loan To Deposit Ratio yang dicapai oleh perusahaan 80,86\%. Pada tahun 2012 Loan To Deposit Ratio yang dicapai mengalami kenaikan, hal ini disebabkan oleh kondisi ekonomi makro yang mulai stabil.Suku bunga relatif tetap karena Bank Indonesia tetap mengawasi tingkat suku bunga yang dipakai oleh bank komersil untuk menghitung suku bunga kredit yang ditentukan. Pada saat bunga pinjaman yang diberikan 
oleh bank rendah maka semakin banyak nasabah yang meminjam dana kepada bank. Selain itu tingkat inflasi pada tahun 2012 relatif stabil. Hal tersebut tercermin dari ekonomi yang tetap tumbuh sebesar 6,2\%. Inflasi pada tahun 2012 masih pada tingkat yang aman. Pada saat tingkat inflasi stabil tingkat harga barang dan jasa juga stabil, sehingga banyak nasabah yang menyimpan dananya di bank. Pada tahun 2013 Loan To Deposit Ratio yang dicapai mengalami kenaikan, hal ini terjadi karena tingkat suku bunga simpanan meningkat., sehingga banyak nasabah yang menyimpan dananya di bank. Ditengah melambatnya pertumbuhan ekonomi di Indonesia, perbankan masih mampu mempertahankan kinerja yang positif, dengan meningkatnya tingkat kredit investasi. Pada tahun 2014 Loan To Deposit Ratio yang dicapai mengalami penurunan, hal ini disebabkan oleh pertumbuhan ekonomi yang sedikit melambat, akibatnya terjadi inflasi. Inflasi menyebabkan harga produk barang dan jasa meningkat. Meningkatnya harga barang dan jasa menyebabkan masyarakat tidak banyak yang menabung uangnya di bank, sehingga bank harus membatasi penyaluran kredit, agar likuiditas bank dalam posisi yang aman. Pada tahun 2015 Loan To Deposit Ratio mengalami kenaikan kembali, hal ini disebabkan oleh pertumbuhan bisnis yang positif dan konsisten, sehingga mendorong penghimpunan dana masyarakat cukup tinggi, dan penyaluran KUR Bank Mandiri juga cukup tinggi.Maulan Irwadi (2014) menyatakan bahwa: "Kestabilan inflasi merupakan prasyarat bagi pertumbuhan ekonomi yang berkesinambungan.....inflasi cenderung menyebabkan menurunnya tingkat tabungan dan atau investasi karena meningkatnya konsumsi masyarakat dan hanya sedikit untuk tabungan jangka panjang. Hal ini menyebabkan jumlah dana yang ada pada bank sedikit dan menurunnya jumlah kredit yang diberikan".

Loan To Deposit Ratiodipengaruhi oleh kondisi ekonomi suatu Negara. Untuk memelihara agar Loan To Deposit Ratiostabildapat dilakukan dengan meningkatkan isu positif bagi nasabah agar tetap tertarik menyimpan atau meminjam dana kepada bank. Isu positif dapat diciptakan dengan membuat kebijakan seperti membuat suku bunga tetap stabil.Sehingga nasabah tetap percaya untuk menyimpan atau meminjam dananya kepada pihak bank.

\section{Laba Operasional pada PT. Bank Mandiri Tbk.}

Laba Operasional pada PT. Bank Mandiri mengalami peningkatan setiap tahunnya, hal tersebut terjadi karena kondisi perekonomian dan perolehanpendapatan dari produk dan jasa perbankan mengalami peningkatan. Selain pendapatan dari bunga kredit pendapatan yang diperoleh bank yaitu pendapatan provisi dan komisi.Pendapatan komisi bank adalah pendapatan yang diterima dari kegiatan jasa. Komisi terdiri dari komisi kirim uang, komisi transaksi kartu kredit, dan lain sebagainya. Pendapatan provisi adalah pendapatan yang diterima dari fasilitas yang telah diberikan. Seperti penerimaan atau pembayaran provisi untuk plafon kredit, provisi bank garansi, iuran tahunan, kartu kredit, dan biaya komitmen.

Pada tahun 2011 Laba Operasional yang dicapai oleh perusahaan sebesar Rp.16.348.933.000. Pada tahun 2012 Laba Operasional yang dicapai mengalami kenaikan, hal ini disebabkan oleh kondisi ekonomi makro yang mulai stabil sehingga suku bunga simpanan maupun suku bunga pinjaman tetap, maka nasabah menyimpan dan meminjam uang kepada bank. Tingkat inflasi yang aman menyebabkan masyarakat menyimpan uangnya di bank. Bagi masyarakat yang sudah meminjam uang, nasabah dapat membayar kewajibannya, karena harga kebutuhan pokok di pasar berada pada nilai yang wajar.Hal ini yang membuat naiknya tingkat kepercayaan masyarakat kepada bank. Sehingga masyarakat merasa aman untuk menyimpan dananya. Pada tahun 2013 Laba Operasional yang dicapai mengalami kenaikan, hal ini terjadi karena tingkat suku bunga simpanan meningkat, sehingga banyak masyarakat yang menabung uangnya di bank. Ditengah melambatnya pertumbuhan ekonomi di Indonesia, perbankan masih mampu mempertahankan kinerja yang positif, dengan meningkatnya tingkat kredit investasi, sehingga pendapatan dari bunga kredit yang diperoleh akan meningkat, dan laba juga akan meningkat. 
Pada tahun 2014 Laba Operasional yang dicapai mengalami kenaikan, hal ini terjadi karena kondisi ekonomi global yang mulai membaik, hal ini berdampak pada kinerja perekonomian nasional, sehingga terjadi mekanisme pasar yang kompetitif untuk produk barang dan jasa. Pendapatan masyarakat akan meningkat dan masyarakat menyimpan uangnya di bank, kemudian oleh bank dapat disalurkan dalam bentuk kredit. Pada tahun 2015 Laba Operasionalmengalami kenaikan kembali, hal ini disebabkan oleh pertumbuhan bisnis yang positif dan konsisten, sehingga mendorong penghimpunan dana masyarakat cukup tinggi, dan penyaluran kredit juga cukup tinggi, sehingga pendapatan yang berasal dari bunga kredit juga meningkat.Hal tersebut sesuai dengan pendapat Al. Haryono Jusup (2011:376) "Laba Operasi adalah hasil dari operasi normal perusahaan yang sedang berlangsung."

Laba dipengaruhi oleh kondisi perekonomian dan perolehan pendapatan produk dan jasa perbankan. Agar tetap menjaga Laba Operasional perusahaan harus mampu melakukan peningkatan kualitas produk dan jasa perbankan dilakukan dengan cara membuat produk dan jasa dilihat dari kebutuhan dan keinginan konsumen. Sehingga produk bank akan semakin diminati oleh nasabah. Bank berupaya menghimpun dana sebanyak mungkin dari masyarakat. Dana tersebut oleh bank dapat disalurkan dalam bentuk kredit. Dari kegiatan kredit tersebut bank akan memperoleh pendapatan bunga kredit yang dapat meningkatkan laba pada Bank Mandiri Tbk.

\section{Pengaruh Loan to Deposit Ratio terhadap Laba Operasional PT. Bank Mandiri Tbk.}

Loan To Deposit Ratio berpengaruh positif dan signifikan terhadap Laba Operasional pada PT. Bank Mandiri. Hal ini disebabkan PT. Bank Mandiri memiliki kinerja usaha yang bagus untuk mendapatkan laba yang optimal.Laba tersebut berasal dari kegiatan utama bank yaitu pendapatan bunga yang berasal dari penyaluran kredit kepada masyarakat.Karena semakin tinggi tingkat Loan To Deposit Ratiomaka akan semakin banyak dana pihak ketiga yang disalurkan dalam bentuk kredit. Dari kegiatan penyaluran kredit tersebut bank memperoleh pendapatan bunga kredit. Dengan semakin banyaknya perolehan bunga kredit maka laba operasional bank meningkat.Hal tersebut sesuai dengan pendapat Nur Aini (2013:14-25) "semakin tinggi Loan To Deposit Ratiomaka laba yang diperoleh bank tersebut meningkat". Maka sesuai dengan pendapat di atas penelitian ini menyatakan bahwa laba yang diperoleh oleh Bank Mandiri meningkat disebabkan oleh Loan To Deposit Ratioyang juga meningkat. Jadi, Loan To Deposit Ratiosangat berpengaruh terhadap Laba Operasional Bank Mandiri.

Untuk semakin meningkatkan pengaruh Loan To Deposit Ratio terhadap Laba Operasional, maka Loan To Deposit Ratioharus ditingkatkan. Hal ini dapat dilakukan dengan cara meningkatkan isu positif agar masyarakat berminat untuk menyimpan dananya di bank. Dana yang berhasil dihimpun tersebut akan disalurkan dalam bentuk kredit. Dari kegiatan kredit maka akan diperoleh pendapatan bunga kredit yang dapat meningkatkan laba operasional di Bank Mandiri.

\section{SIMPULAN}

Berdasarkan hasil penelitian dan pembahasan yang penulis sajikan, maka dapat disimpulkan bahwa:

1. Tingkat Loan To Deposit Ratio pada Bank Mandiri selama lima tahun mengalami fluktuasi disebabkan ekonomi makro yang tidak stabil, tingkat suku bunga dan tingkat inflasi. Namun, Loan To Deposit Ratio pada Bank Mandiri masih pada batas yang wajar yaitu di bawah $110 \%$, artinya penyaluran dana pihak ketiga untuk kredit pada Bank Mandiri sangat baik. 
2. Tingkat Laba operasional pada Bank Mandiri selama lima tahun megalami kenaikan pada setiap tahunnya dikarenakan pertumbuhan bisnis yang positif dan konsisten sehingga mendorong penghimpunan dana masyarakat dan penyaluran kredit cukup tinggi.

3. Terdapat pengaruh Loan To Deposit Ratio terhadap labaoperasional pada Bank Mandiri.

\section{DAFTAR RUJUKAN}

Arikunto, S. (2013). Prosedur Penelitian Suatu Pendekatan Praktik. Jakarta: PT. Rineka Cipta. Bursa Efek Indonesia. (2015). Jakarta: http//www.idx.co.id.

Darmadi, H. (2013). Metode Penelitian Pendidikan. Bandung: Alfabeta.

Dendawijaya, L. (2005). Manajemen Perbankan. Bogor: Ghalia Indonesia.

Ghozali, I \& Chariri, A. (2007). Teori Akuntansi. Semarang: Penerbit Universitas Diponegoro.

Hendro, T \& Conny. (2014). Bank dan Institusi Keuangan Non Bank di Indonesia. Yogyakarta: UPP STIM Yogyakarta.

Huda, M. (2013). Model-Model Pengajaran dan Pembelajaran. Yogyakarta: Pustaka Pelajar.

Iskandar, S. (2008). Bank dan Lembaga Keuangan Lain. Jakarta: PT. Semesta Asa Bersama.

Ismail. (2015). Akuntansi Bank Teori Aplikasi dalam Rupiah. Edisi Revisi. Jakarta: Prenadamedia Group.

Jusup, A.H. (2011). Dasar-dasar Akuntansi. Yogyakarta: UPP STIM Yogyakarta.

Kasmir. (2011). Dasar-dasar Perbankan. Cetakan Kesembilan. Jakarta: PT. RajaGrafindo Persada.

Kasmir. (2011). Manajemen Perbankan. Cetakan Kesepuluh. Jakarta: PT. RajaGrafindo Persada.

Retnadi, D. (2006). Memilih Bank yang Sehat. Jakarta: PT. Elex Media Komputindo.

Riduwan. (2012). Dasar-dasar Statistika. Cetakan Kesepuluh. Bandung: Alfabeta.

Shoimin, A. (2014). 68 model pembelajaran inovatif dalam pemebelajaran kurikulum 2013. Yogyakarta: AR-Ruzz Media.

Sipahutar, M.A. (2007). Persoalan-Persoalan Perbankan Indonesia. Jakarta: PT. Niaga Swadaya.

Smith J.M \& Skousen. (1997). Alih Bahasa Alfonsus S. Akuntansi Intermediate. Jakarta: PT. Gelora Aksara Pratama.

Soemarso. (2004). Akuntansi Suatu Pengantar. Jakarta: Salemba Empat.

------, (2005). Akuntansi Suatu Pengantar. Edisi 5. Jakarta: Salemba Empat.

Sugiyono. (2013). Statistika untuk Penelitian. Bandung: Alfabeta.

------., (2014),Metode Penelitian Kuantitatif Kualitatif dan R\&D. Bandung. Alfabeta.

Taswan. (2010). Manajemen Perbankan. Edisi 2. Yogyakarta: UPP STIM Yogyakarta.

Aini, N. (2013). Pengaruh Car, Nim, Ldr, Bopo, dan Kualitas Aktiva Produktif Terhadap Perubahan Laba. Jurnal Dinamika Akuntansi, Keuangan dan Perbankan. Online, Volume 2; No.2 (https://www.unisbank.ac.id/ojs/index.php/fe9/article/download/2104/772), diakses 10 Juni 2017.

Irwandi, M. (2014). Pengaruh Inflasi dan BI Rate Terhadap Laba Perbankan di Indonesia. Jurnal OCPUS. Online, Volume VI; No. 2 https://www.academia.edu/15525922/pengaruh_inflasi_dan_bi_rate_terhadap_laba_perba nkan_di_indonesia), diakses 10 Juni 2017.

Widiawati, H.S. (2013). Analisis Biaya, Volume Penjualan dan Laba Sebagai Alat Bantu Perencanaan Laba Pada UD. Wahyu Lestari Kabupaten Kediri.EFEKTOR No.22 (http://lp2m.unpkediri.ac.id/jurnal/pages/efektor/Nomor22/hal\%2015.\%20HESTIN.pdf) diakses 10 juni 2017. 


\section{Sosio e-kons}

Volume 10, No. 3, Desember 2018, pp. 253-260

e-ISSN: 2502-5449

p-ISSN: 2085-2266

http://journal.lppmunindra.ac.id/index.php/sosio_ekons

Yuliawati, I. (2011). Analisis Faktor yang Mempengaruhi Laba dan "Arus Kas" Masa Depan Pada Perusahaan Go Public.http://journal.trunojoyo.ac.id/infestasi/article/view/489/1511) , diakses 10 Juni 2017. 